\title{
Familial aggregation of coronary heart disease in a high incidence area (North Karelia, Finland)
}

\author{
AILA M. RISSANEN \\ From the Third Department of Medicine, University of Helsinki, Helsinki, Finland
}

SUMMARY Occurrence of coronary heart disease was assessed in families of 211 men under the age of 56 from East Finland. Fifty men were survivors of recent myocardial infarctions, 55 had died of myocardial infarction, 53 suffered from uncomplicated angina pectoris, and 53 were healthy reference men. Overall prevalence of coronary heart disease was similar in families of all case probands. By age 70, case fathers had a 6 times greater cumulative risk (a $36 \%$ chance) of dying from coronary heart disease than reference fathers, whereas there was only a small difference between case and reference mothers. Cumulative risk of developing fatal or non-fatal coronary heart disease by age 65 was $4 \cdot 5$-fold for case brothers $(70 \%)$ and $2 \cdot 6$-fold for case sisters $(40 \%)$, when compared with reference sibs. The risk was greatest for case sibs with a parental, especially a maternal, history of premature coronary heart disease. Clinical manifestations of coronary heart disease showed similarities within sibships. Cardiac deaths were commonest in sibs of the fatal myocardial infarction probands, whereas angina was commonest in sibs of the angina pectoris probands.

With the precipitous rise in the frequency of coronary heart disease, study of its aetiology has focused on the role of environment; less information has accumulated about genetic factors. The existence of some hereditary basis for coronary heart disease has been recognised, however, in early clinical impressions (White, 1960). Aside from some twin (Cederlöf et al., 1967; Harvald and Hauge, 1970; Liljefors, 1970; De Faire et al., 1975) and population studies (Epstein and Kjelsberg, 1965; Hammond et al., 1971; Sholtz et al., 1975), most of the evidence of a genetic component in coronary heart disease has been derived from case-control studies of families (Gertler and White, 1954; Thomas and Cohen, 1955; Russek and Zohman, 1958; Shanoff et al., 1961; Rose, 1964; Slack and Evans, 1966; Phillips et al., 1974). Though beset with many methodological problems (Haenszel, 1950; Epstein, 1964; Murphy, 1967; Napier et al., 1972), these have uniformly shown a higher frequency of the disease in the families of coronary heart disease cases than in the families of controls.

From what is known it appears that coronary heart disease shows a modest, generally two- to threefold increase in frequency in families of coronary patients. Similar familial concentrations have been found also for most other chronic

Received for publication 19 February 1979 diseases for which they have been sought (Edwards, 1963). The degree of aggregation of coronary heart disease appears to be greater, however, in families of young patients with coronary heart disease (Shanoff et al., 1961; Slack and Evans, 1966), in particular in fatal forms of the disease (Deutscher et al., 1970). Consequently, in populations known to have a high incidence of fatal coronary heart disease in the young, familial aggregation of coronary heart disease may be more distinct than elsewhere.

Finland is a country with the world's highest morbidity and mortality from coronary heart disease in young and middle-aged men (Epstein and Krueger, 1969). Within the country, pronounced geographical differences exist in the rate of coronary heart disease; the incidence and mortality are highest in the east (particularly in the province of North Karelia).

The objectives of this study were firstly to establish whether, and to what extent, coronary heart disease aggregates within families of relatively young men with coronary heart disease in this area where the incidence of the disease is exceedingly high, and, secondly, to establish whether there are any differences in the degree of aggregation in families of men who develop either non-fatal or fatal myocardial infarction, or angina pectoris.

In subsequent reports, data on the risk factor levels in these families as well as comparison of the 
present findings with those in a region of Finland with a lower incidence of coronary heart disease will be given.

\section{Subjects and methods}

\section{PROBANDS}

Non-fatal myocardial infarction

The probands were 50 consecutive survivors of myocardial infarction among men under the age of 56 admitted to hospitals during a $2 \frac{1}{2}$-year period in 1972 to 1974 in 2 neighbouring communities in North Karelia. The list of myocardial infarction cases was based on hospital records only, but it proved to be identical with the list collected from all available sources by the WHO's myocardial infarction register operating in the same communities (Puska and Mustaniemi, 1975).

The non-fatal myocardial infarction probands had to meet the following criteria: (1) definite myocardial infarction (World Health Organization, 1971), that is either unequivocal electrocardiographic evidence of a recent myocardial infarction, or diagnostic changes in serum enzyme pattern together with either suggestive electrocardiographic changes or a typical history of chest pain; and (2) survival for more than 28 days after the attack, with no fatal recurrence by the end of 1974 . Of the 50 eligible men, 16 had had at least 1 clinical myocardial infarction before the present attack. The age of the non-fatal myocardial infarction probands ranged from 33 to 55 years (mean $48 \cdot 8$ years).

\section{Fatal myocardial infarction}

The probands were consecutive fatal cases of verified coronary heart disease that occurred among men under age 56 during a $2 \frac{1}{2}$-year period in 1972 to 1974 in the same communities as above and in the immediate surrounding area. The death certificates with Code Nos. 410-414 (International Classification of Diseases, Injuries and Causes of Death (ICD), 8th revision) from the study communities were obtained from the Central Statistical Office in Finland. The hospital records, necropsy findings, information from local physicians, and other pertinent data were collected for each case. The cause of death was determined after a review of these documents. The criteria for accepting coronary heart disease deaths were the following: either (1) definite myocardial infarction (World Health Organization, 1971), with survival less than 28 days, or positive postmortem evidence of recent myocardial infarction; or (2) possible myocardial infarction (World Health Organization, 1971), that is cases in which the fatal event was preceded by a history of chest pain as well as either previous symptoms of coronary heart disease or suggestive necropsy findings such as old myocardial infarct scars or severely affected coronary arteries. These criteria were met by 60 men.

The closest relatives of the fatal myocardial infarct probands were sought with the aid of local church, postal, and police personnel, and the search was unsuccessful for only 5 probands.

The age of the 55 fatal myocardial infarct probands included in the study ranged from 22 to 55 years (mean 46.3 years). Before the fatal attack, coronary heart disease had been diagnosed in 38 men, 21 of whom had suffered clinical myocardial infarction. Death was sudden (within 1 hour from the onset of the symptoms) in one-half of the cases. One-quarter of the cases came to necropsy.

\section{Angina pectoris}

The probands were screened from the records of occupational health examinations performed between 1970 and 1974 on about 3000 men employed by large wood and paper companies in the same communities from which the other probands were selected. Employees with resting electrocardiographic abnormalities (Minnesota Code Nos. 1.2-3, $4.1-3,5.1-3,6.1-2,7.1-2$ or 8.3 ) (450 men) were examined by the author. Fifty-three men were judged to have clinical angina pectoris without evidence of past myocardial infarction or a secondary cause for angina. These men constitute the angina pectoris probands of this study. ST changes were seen in the resting electrocardiograms of one-half of the selected men, in one-third there were $T$ changes only. Definite coronary heart disease had been diagnosed earlier in 38 men, and 15 of them had retired because of the disease. The duration of angina pectoris symptoms varied from 3 to 99 months. The age of the probands ranged from 27 to 55 years (mean $49 \cdot 5$ years).

\section{Reference men}

The reference probands were selected from the same employee rosters as the angina pectoris probands. For each angina pectoris proband, 2 prospective reference men matched for age and marital status were selected from the same occupational speciality. The one of the two whose date of birth was closest to that of the respective angina pectoris proband was finally selected unless he had symptoms suggestive of coronary heart disease.

The living probands, their spouses, and the closest relatives of the deceased probands were examined by the author. All first-degree relatives were listed, and consent was obtained to contact these and to obtain the death certificates from any deceased family members. 


\section{RELATIVES}

The probands had 812 living and 517 deceased parents and sibs. The status of 42 relatives was unknown. The living relatives were sent a questionnaire on their medical history, and asked to report to local medical laboratories where resting 12-lead electrocardiograms were recorded (from relatives past age 40) and advice was available for filling out the questionnaire. The questionnaire and the recorded data were then forwarded to Helsinki University Hospital for analysis. The information requested was obtained from $721(88.8 \%)$ of the living relatives.

The number of living and deceased participants in different study groups is shown in Table 1. Parents and sibs who had died before the age of 30 were not included in the study. The distribution of the birth dates of participating relatives was similar in all study groups (Fig. 1). The mean age for both the living sisters and brothers was $47 \cdot 0$ years.

\section{Data from relatives}

The questionnaires obtained from the relatives yielded information about previous diagnoses of cardiovascular diseases, and about present medication and health. The questionnaires were, in general, well completed; a few incomplete ones were amended by mail or telephone. To assess the reliability of the questionnaire data, a sample of 145 relatives was invited to have a clinical examination. Ninety-one per cent of them complied and were examined. The reporting of diagnosed coronary heart disease and of other cardiovascular diseases appeared to be reliable.

The reported diagnoses of coronary heart disease were standardised by checking them against the records of hospitals and private physicians. The diagnosis of past myocardial infarction was accepted only when the records reviewed disclosed unequivocal changes in the electrocardiogram or in serum enzyme pattern. Other cases of reported coronary heart disease (referred to here as 'other clinical coronary heart disease') were accepted only if the available data also described the basis of the diagnosis. The reported diagnosis of coronary heart disease could not be confirmed in 6 cases.

The electrozardiograms were coded by a trained technician using the Minnesota Code. Approximately every sixth recording was coded also by a second reader. The agreement between the two was good.

The causes of death of the deceased relatives were registered from death certificates, which were available for 95 per cent of the cases. To avoid the bias caused by changes in the nomenclature in earlier editions of ICD, the primary cause of death was recorded according to the latest (1965) revision of the classification in the Central Statistical Office of Finland. Approximately 75 per cent of the confirmed coronary heart disease deaths were so reported also by the relatives. Most errors in reporting were on the side of underreporting. In addition, all the available hospital records of the deceased sibs were reviewed. These records did not disclose coronary heart disease in any of the cases in which the primary cause of death was not coronary heart disease.

\section{METHODS OF DATA ANALYSIS \\ Life tables}

Life tables were obtained for the sibs, fathers, and mothers of the probands by the method of Cutler and Ederer (1958). The parents and sibs were entered on the tables at the age of 30 , and they were withdrawn at the end of 1974 or at the age of death if they had died before that date. Life tables were constructed for mortality from all causes, from all cardiovascular diseases (ICD Nos. 400-450) and from coronary heart disease $(410-414)$. A second type of life table was also constructed for combined morbidity and mortality from coronary heart disease. The occurrence of non-fatal coronary heart disease was made analogous to death from coronary heart disease, and the affected relatives were withdrawn at the age of their first coronary heart disease event, or at the age of death in the fatal cases in which the age of the first event was unknown.

The differences in the cumulative probabilities of

Table 1 Number of participants in different study groups

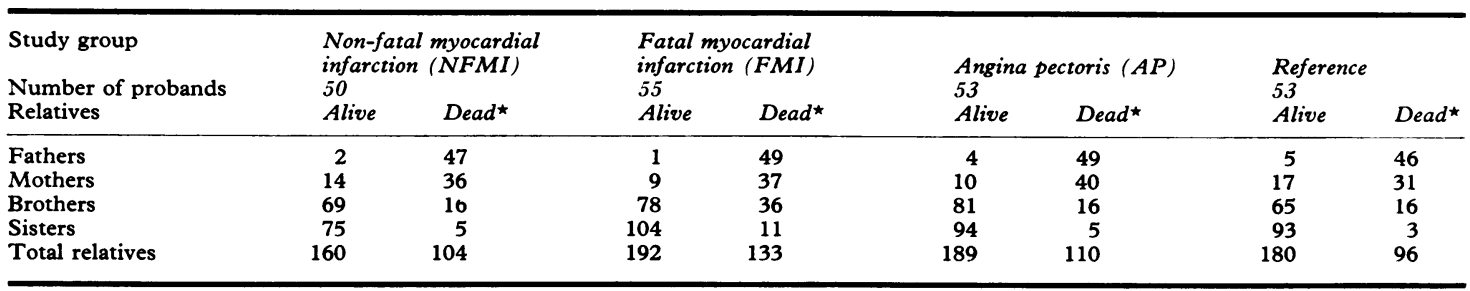

$\star$ Deceased who survived to age 30 are included. 


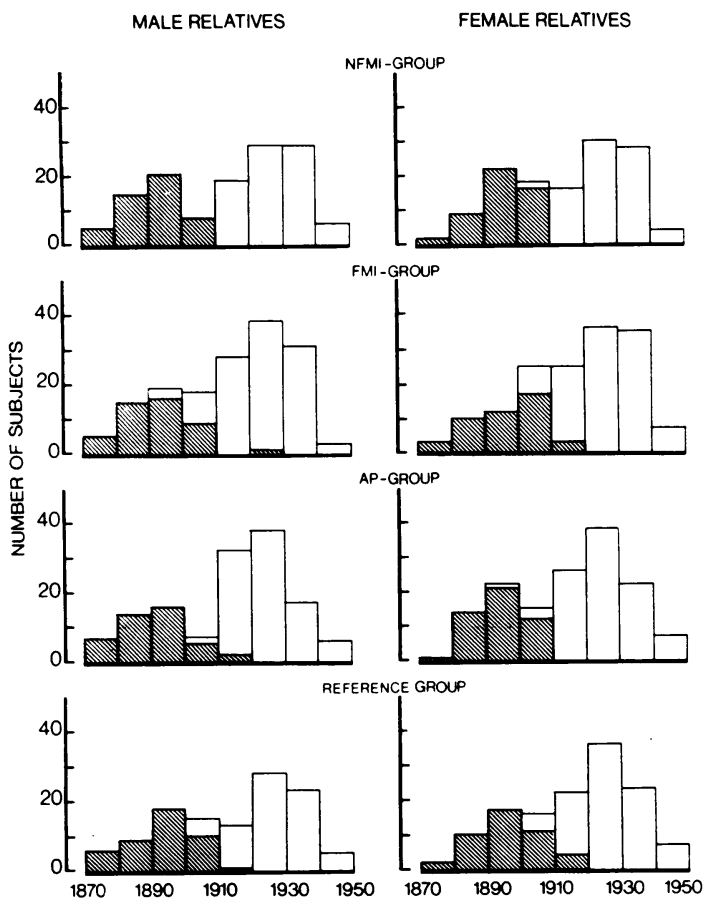

Fig. 1 Distribution of deceased $(\square)$ and living $(\square)$ participants by year of birth.

an event between two groups of relatives were tested according to Mantel (1966). The test evaluates the differences between the life table patterns in their entirety rather than at isolated points only.

For statistical testing of qualitative variables, the $x^{2}$ test was used. The effect of multiple (nonindependent) observations within a family was disregarded in all statistical tests of the study. Hence the significance tests described will have to be interpreted as rough measures of strength of association between the variables.

In the following text, the non-fatal myocardial infarction, fatal myocardial infarction, and angina pectoris groups will of ien be referred to jointly as case groups.

\section{OCCURRENCE OF CORONARY HEART DISEASE}

\section{AMONG RELATIVES}

\section{Parents}

About 90 per cent of both case and reference fathers were deceased. One-third of case fathers and onefifth of reference fathers had died of coronary heart disease $(P<0.05)$. There were no appreciable differences in the total mortality nor in the mortality from specified causes between the fathers of the non-fatal myocardial infarction, fatal myocardial infarction, and angina pectoris probands.

Curves of the cumulative probabilities of dying from all causes, from all cardiovascular causes, and from coronary heart disease for all case fathers and reference fathers are presented in Fig. 2. The risk of fatal coronary heart disease was much higher for case fathers than for reference fathers.

By the age of 70 , case fathers had a 36 per cent chance of dying from coronary heart disease, which denotes an approximately sixfold excess in cumulative risk over the risk of reference fathers $(P<$ 0.01 ). However, the difference in risk decreased with advancing age. Cerebrovascular deaths were also slightly more common among case than reference fathers, whereas mortality from other causes was slightly lower in case group than in reference group. The slightly higher overall mortality of case fathers could thus be totally attributed to the increased rate of cardiovascular disease.

The cumulative risk of dying before the age of 70 for case mothers was $2 \cdot 0$ times greater for case than for reference mothers $(\mathbf{P}<0.05)$ (Fig. 3). At later

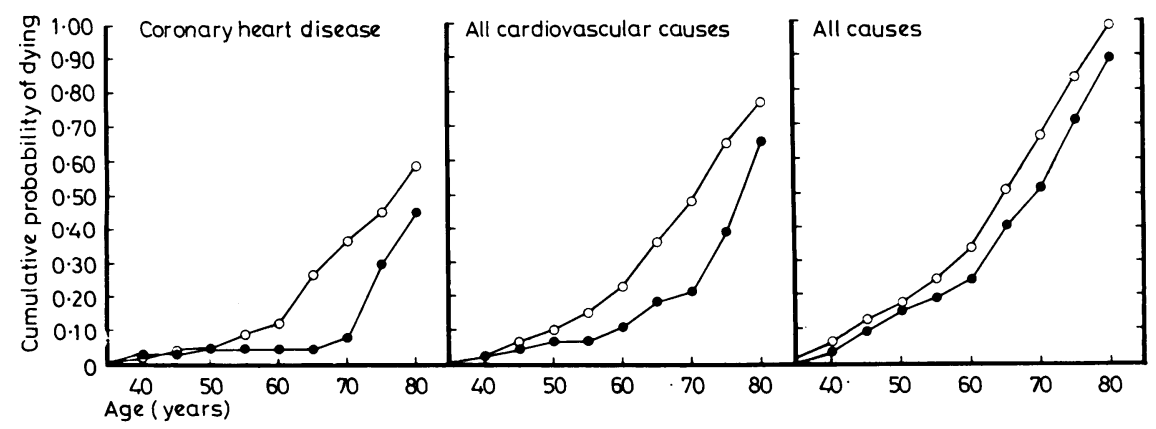

Fig. 2 Cumulative probability of case (-O $\longrightarrow$ ) and reference (- $\longrightarrow$ ) fathers of dying from coronary heart disease (International Classification of Diseases Code Nos. 410-414), from all cardiovascular causes (400-450), and from all causes. 


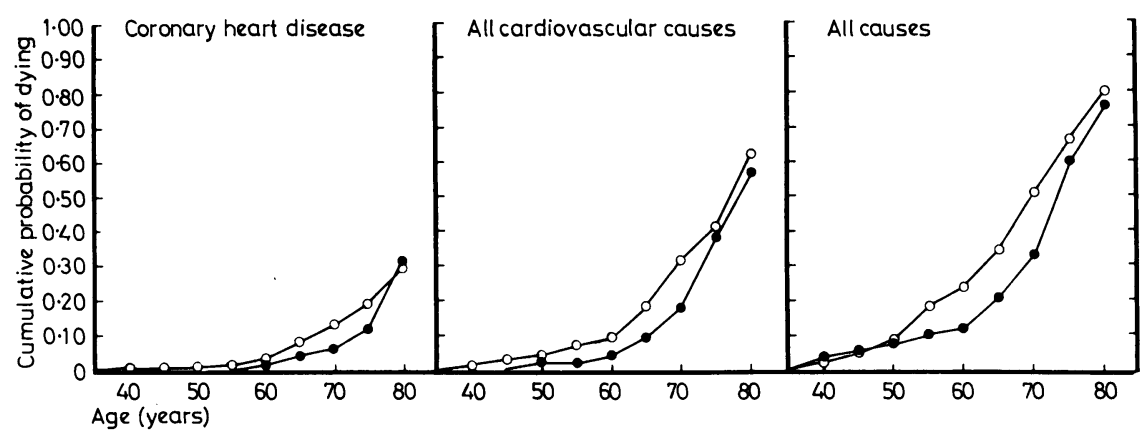

Fig. 3 Cumulative probability of case (- $-\longrightarrow$ ) and reference (- - - mothers of dying from coronary heart disease, all cardiovascular causes, and from all causes.

ages, the difference in risk was not apparent. The increased risk of case mothers was mostly, but not totally, attributable to cardiovascular disease. The mortality of mothers of the non-fatal myocardial infarction, fatal myocardial infarction, and angina pectoris probands was similar.

\section{Brothers}

Approximately one-third of the brothers of the nonfatal myocardial infarction, fatal myocardial infarction, and angina pectoris probands had developed fatal or non-fatal coronary heart disease (Table 2). The frequencies are 3.5 times greater than for reference brothers $(P<0.001)$.

Curves of the cumulative probabilities of developing coronary heart disease for case and reference brothers are shown in Fig. 4. The risk of coronary heart disease for case brothers was 44 per cent by the age of 55 , and increased to 70 per cent by the age of 65 ; the cumulative risk of coronary heart disease by this age was 4.5 times greater for case brothers than for reference brothers $(P<0.001)$.

There were some differences between the clinical manifestations of coronary heart disease in the various case groups. Among the brothers of the probands who had suffered fatal myocardial infarction, cardiac deaths predominated, whereas the brothers of the non-fatal myocardial infarction and angina pectoris probands tended to develop mostly non-fatal forms of coronary heart disease (Table 3 ).

\section{Sisters}

Coronary heart disease had been diagnosed in approximately 12 per cent of the sisters of the affected probands, which is twice as frequently as in reference sisters $(P=0.09)$ (Table 4). The probability of developing fatal or non-fatal coronary heart disease for case sisters was 20 per cent by age 55. The risk doubled within the next decade, and by age 65 there was a $2 \cdot 6$-fold excess in cumulative risk of coronary heart disease for case sisters over that for reference sisters $(P<0.05)$ (Fig. 4). As also noticed among the brothers, coronary heart disease was often fatal among the sisters of the fatal myocardial infarction probands, whereas other clinical forms of coronary heart disease prevailed in the other groups (Table 3).

\section{Electrocardiographic abnormalities}

Ischaemic electrocardiographic abnormalities, defined as Minnesota Code Nos. 1.1-3, 4.1-3, 5.1-2, were significantly more common among case sibs than among reference sibs $(16 \cdot 4 \%$ vs. $7 \cdot 4 \%$, $P<0.01$ ) (Table 5). Furthermore, electrocardio-

Table 2 Frequency of clinical coronary heart disease in brothers

\begin{tabular}{|c|c|c|c|c|c|c|c|}
\hline \multirow{2}{*}{ Study group } & \multirow{2}{*}{$\begin{array}{l}\text { Number of } \\
\text { brothers }\end{array}$} & \multicolumn{6}{|c|}{ Number of cases with clinical coronary heart disease } \\
\hline & & $\begin{array}{l}\text { Fatal } \\
\text { myocardial } \\
\text { infarction }\end{array}$ & $\begin{array}{l}\text { Non-fatal } \\
\text { myocardial } \\
\text { infarction }\end{array}$ & $\begin{array}{l}\text { Other forms } \\
\text { of coronary } \\
\text { heart disease }\end{array}$ & $\begin{array}{l}\text { All coronary } \\
\text { heart disease }\end{array}$ & $(\%)$ & $\begin{array}{l}\text { Risk } \\
\text { ratio }\end{array}$ \\
\hline $\begin{array}{l}\text { NFMI } \\
\text { FMI } \\
\text { AP } \\
\text { All case } \\
\text { Reference }\end{array}$ & $\begin{array}{r}85 \\
114 \\
97 \\
296 \\
81\end{array}$ & $\begin{array}{r}10 \\
19 \\
8 \\
37 \\
1\end{array}$ & $\begin{array}{r}4 \\
10 \\
9 \\
23 \\
2\end{array}$ & $\begin{array}{r}11 \\
15 \\
18 \\
44 \\
5\end{array}$ & $\begin{array}{c}25 \\
44 \\
35 \\
104^{\star} \\
8\end{array}$ & $\begin{array}{r}(29.4) \\
(38.6) \\
(36.1) \\
(35.1) \\
(9.9)\end{array}$ & $\begin{array}{l}3.0 \\
3.9 \\
3.6 \\
3.5 \\
1.0\end{array}$ \\
\hline
\end{tabular}

$\star P<0.001$ for the difference between all case groups and reference group. 


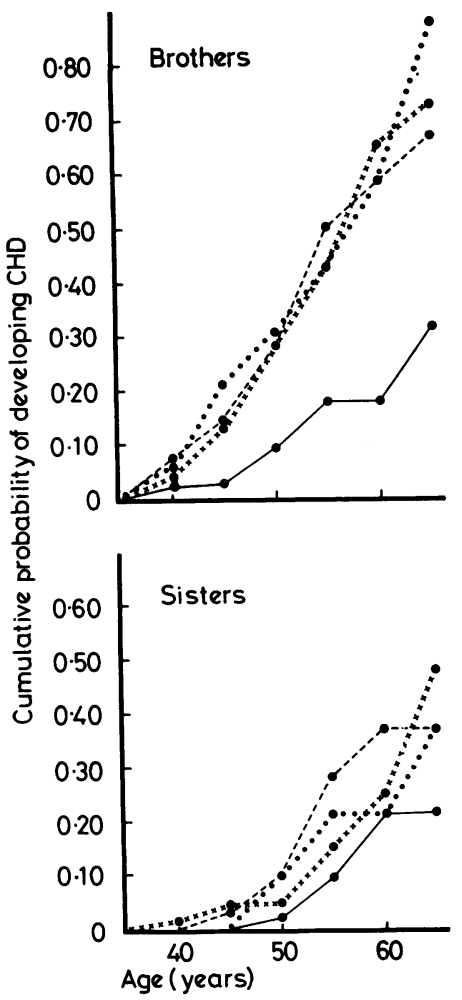

Fig. 4 Cumulative probability of developing fatal or non-fatal coronary heart disease of the sibs of the non-fatal myocardial infarction-(xxx), fatal myocardial

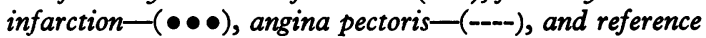
$(\longrightarrow)$ probands.

graphic abnormalities were more common among the sibs of the angina pectoris probands than among other case sibs $(22.9 \%$ vs. $12.9 \%, P<0.01)$. The increased prevalence of ischaemia was noted also among those sibs of the angina pectoris probands who were free of clinical coronary heart disease.

Signs of probable old myocardial infarction (Minnesota Code Nos. 1.1, $1.2+5.1$ or $1.2+5.2$ )
Table 3 Cumulative probability of fatal coronary heart disease for sibs before age $60(\%)$

\begin{tabular}{lllll}
\hline Study group & $\begin{array}{l}\text { Fatal } \\
\text { myocardial } \\
\text { infarction }\end{array}$ & $\begin{array}{l}\text { Non-fatal } \\
\text { myocardial } \\
\text { infarction }\end{array}$ & $\begin{array}{l}\text { Angina } \\
\text { pectoris }\end{array}$ & Reference \\
\hline Brothers & $34.5^{\star}$ & $28.9 \star$ & $15 \cdot 4 \dagger$ & 4.4 \\
Sisters & 8.2 & 3.5 & - & - \\
\hline
\end{tabular}

$\star P<0.01$ for the difference between fatal myocardial infarction/ non-fatal myocardial infarction group and reference group.

$+\mathrm{P}<0.05$ for the difference between angina pectoris group and reference group.

were present in 5.0 per cent of the electrocardiographic tracings of case brothers. In only 2 brothers had the myocardial infarction been clinically silent. Signs of old myocardial infarction were present in the electrocardiograms of 1.4 per cent of case sisters. None of the myocardial infarctions in women had gone clinically undetected.

RELATION OF PARENTAL HISTORY TO CORONARY HEART DISEASE IN THE FAMILY There were 14 case families in which the mother had died of coronary heart disease before age 70 . The risk of coronary heart disease was exceptionally great for the offspring of these mothers (Table 6). By age 55, the risk for their daughters was 41 per cent, 3 times greater than that for the remaining case sisters $(P<0.01)$, and for their sons (other than probands) the risk was 63 per cent, which denotes a twofold increase over the risk for the remaining case brothers $(P<0.05)$.

Thirty-eight case fathers had died of coronary heart disease before the age of 70 . The risk of coronary heart disease was slightly increased for the offspring of these fathers, when compared with the risk for the offspring of case families without any parental history of premature coronary heart disease (Table 6). The risk appeared to be more distinctly increased for the offspring of fathers who died of coronary heart disease before the age of 60 ,

Table 4 Frequency of clinical coronary heart disease in sisters

\begin{tabular}{|c|c|c|c|c|c|c|c|}
\hline \multirow{2}{*}{ Study group } & \multirow{2}{*}{$\begin{array}{l}\text { Number of } \\
\text { sisters }\end{array}$} & \multicolumn{6}{|c|}{ Number of cases with clinical coronary heart disease } \\
\hline & & $\begin{array}{l}\text { Fatal } \\
\text { myocardial } \\
\text { infarction }\end{array}$ & $\begin{array}{l}\text { Non-fatal } \\
\text { myocardial } \\
\text { infarction }\end{array}$ & $\begin{array}{l}\text { Other forms } \\
\text { of coronary } \\
\text { heart disease }\end{array}$ & $\begin{array}{l}\text { All coronary } \\
\text { heart disease }\end{array}$ & $(\%)$ & $\begin{array}{l}\text { Risk } \\
\text { ratio }\end{array}$ \\
\hline $\begin{array}{l}\text { NFMI } \\
\text { FMI } \\
\text { AP } \\
\text { All case } \\
\text { Reference }\end{array}$ & $\begin{array}{r}80 \\
115 \\
99 \\
294 \\
96\end{array}$ & $\begin{array}{l}\frac{2}{3} \\
\frac{5}{-}\end{array}$ & $\begin{array}{l}3 \\
2 \\
4 \\
9 \\
-\end{array}$ & $\begin{array}{r}4 \\
7 \\
11 \\
22 \\
6\end{array}$ & $\begin{array}{c}9 \\
12 \\
15 \\
36^{\star} \\
6\end{array}$ & $\begin{array}{r}(11 \cdot 3) \\
(10 \cdot 4) \\
(15 \cdot 2) \\
(12 \cdot 2) \\
(6 \cdot 3)\end{array}$ & $\begin{array}{l}1.8 \\
1.7 \\
2.4 \\
2.0 \\
1.0\end{array}$ \\
\hline
\end{tabular}

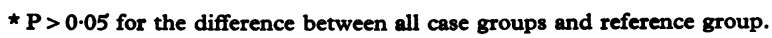


Table 5 Frequency of ischaemic changes ${ }^{\star}(\%)$ in resting electrocardiograms of sibs over age 40

\begin{tabular}{lllll}
\hline & \multicolumn{2}{c}{ Brothers } & Sisters \\
\cline { 2 - 5 } Study group & All & $\begin{array}{l}\text { Without } \\
\text { clinical } \\
\text { coronary } \\
\text { heart } \\
\text { disease }\end{array}$ & All & $\begin{array}{l}\text { Without } \\
\text { clinical } \\
\text { coronary } \\
\text { heart } \\
\text { disease }\end{array}$ \\
\hline $\begin{array}{l}\text { Non-fatal myocardial } \\
\text { infarction }\end{array}$ & 8.5 & 5.6 & 14.5 & 9.1 \\
$\begin{array}{l}\text { Fatal myocardial } \\
\text { infarction }\end{array}$ & 19.6 & 9.1 & 9.3 & 6.1 \\
$\begin{array}{l}\text { Angina pectoris } \\
\text { Reference }\end{array}$ & $22.0 \dagger$ & 9.1 & $23.6 \dagger$ & 14.0 \\
\hline
\end{tabular}

* Minnesota Code 1.1-3, 4.1-3, 5.1-2.

$+\mathrm{P}<0.01$ for the difference between the sibs of AP-group and reference group

but the number of subjects at risk was too small to warrant any firm conclusions.

The risk of coronary heart disease was similar for the offspring of families with a parental history of coronary heart disease past the age of 70 and for the offspring of families without any parental history of coronary heart disease. However, when both parents had died of coronary heart disease at a later age, there appeared to be a slight increase in the risk of coronary heart disease for the offspring.

There were 5 reference families with a history of fatal coronary heart disease before the age of 70 in one of the parents. One-half of the cases of coronary heart disease among reference sibs came from these families. This denotes an eightfold increase in the risk of coronary heart disease for the offspring of the affected reference parents, compared with the risk for the offspring of non-affected parents.

\section{FAMILY CLUSTERING OF CORONARY HEART DISEASE}

Distinct familial clustering of coronary heart disease

Table 6 Cumulative probability of developing coronary heart disease by age 55 (\%) for case sibs according to parental coronary heart disease

\begin{tabular}{|c|c|c|}
\hline & Brothers & Sisters \\
\hline $\begin{array}{l}\text { Mother died of coronary heart disease } \\
\text { before age } 70\end{array}$ & $63 \cdot 3 \star$ & $41 \cdot 4 \dagger$ \\
\hline $\begin{array}{l}\text { Father died of coronary heart disease } \\
\text { before age } 70\end{array}$ & $42 \cdot 7$ & 28.9 \\
\hline $\begin{array}{l}\text { Neither parent died of coronary heart } \\
\text { disease before age } 70\end{array}$ & $40 \cdot 2$ & $14 \cdot 6$ \\
\hline
\end{tabular}

was present in one-third of case families (Table 7). These families had a minimum of 3 members affected by coronary heart disease, accounting for two-thirds of the total cases of coronary heart disease in the case group. Impressive clustering of coronary heart disease was not confined to the families with a history of early coronary death in a parent. There were 3 to 7 affected sibs in 16 families in which neither parent had died of coronary heart disease before the age of 70 .

\section{Discussion}

In the present study, a major effort was made to avoid the biases common to family studies of coronary heart disease (Haenszel, 1950; Epstein, 1964; Murphy, 1967; Napier et al., 1972). No hearsay evidence of coronary heart disease was accepted. All information was collected directly from the relatives, verified by medical records, and reviewed in a standardised way to exclude the diagnoses established by intuition or family history only. By these means, most false positive diagnoses were likely to be eliminated, but also some real cases of coronary heart disease may have been missed. Furthermore, the selection of probands in the present study was not restricted to patients in hospital. The myocardial infarction probands were the consecutive incidence cases of myocardial infarction within whole communities. The selection of the angina pectoris probands was by necessity, however, more restricted. Only a small, perhaps the most severe (Frank et al., 1973), fraction of clinical angina pectoris could be included; incidence cases of angina most probably would include, along with true angina, such heterogeneous conditions as preinfarction angina and early stages of other, even non-cardiac, diseases. Nevertheless, the angina pectoris probands were selected by uniform criteria from a group that is fairly representative of the male

Table 7 Distribution of cases of coronary heart disease in families (proband excluded)

\begin{tabular}{lllll}
\hline & $\begin{array}{l}\text { Non-fatal } \\
\text { myocardial } \\
\text { infarction }\end{array}$ & $\begin{array}{l}\text { Fatal } \\
\text { myocardial } \\
\text { infarction } \\
\text { Study group }\end{array}$ & $\begin{array}{l}\text { Angina } \\
\text { pectoris } \\
55\end{array}$ & Reference \\
Number of families & 50 & 53 & 53 \\
\hline Number of family & & & & \\
$\quad$ members with & & & & \\
coronary heart & $\%$ & $\%$ & $\%$ & $\%$ \\
disease & 34.0 & 20.0 & 24.5 & $52 \cdot 8$ \\
1 & 28.0 & 41.8 & 41.5 & 32.1 \\
2 & 28.0 & 16.4 & 18.9 & 11.3 \\
3 & 4.0 & 12.7 & 7.5 & 3.8 \\
4 or more & 6.0 & $9 \cdot 1$ & 7.5 & - \\
\hline
\end{tabular}

$P<0.01$ between non-fatal myocardial infarction/fatal myocardial infarction/angina pectoris families and reference families. 
population in the industrialised communities of the study. Likewise, though not selected from the population at large, the reference probands were fairly representative of men of their age in the study communities. Even if somewhat better health than that found in the general population could be expected in this group of mostly employed men, free of any symptoms of coronary heart disease (McMichael et al., 1975), the morbidity and mortality of the relatives of these probands appeared to be very similar to that of the general population in Finland, if judged from the preliminary data available from a population study of 50000 Finns (A. Aromaa, unpublished results).

In the present study, the degree of familial aggregation of coronary heart disease appeared to be similar in the non-fatal myocardial infarction, fatal myocardial infarction, and angina pectoris groups. However, distinct differences between the groups were found as to the predominant clinical manifestation of the disease. While fatal coronary heart disease predominated among the sibs in the fatal myocardial infarction group, non-fatal coronary heart disease was most common among the sibs of the angina pectoris probands. Furthermore, the frequency of ischaemic electrocardiographic abnormalities without clinical coronary heart disease, which perhaps is equivalent to preclinical disease, was highest in this group. Similar familial resemblance in the clinical manifestations of coronary heart disease as observed here was found also in an area of Finland with a lower incidence of coronary heart disease (unpublished observations). These observations suggest that familially determined differences may exist in the atherosclerotic process underlying the various clinical manifestations of coronary heart disease. Alternatively, the trigger mechanisms behind the various clinical manifestations of coronary heart disease may be familially determined.

The dezree of familial aggregation of coronary heart disease observed in this study is similar to that of most other studies. An excess mortality from coronary heart disease among case fathers, especially among fathers of young probands, has been reported before (Shanoff et al., 1961; Rose, 1964; Slack and Evans, 1966; Deutscher et al., 1970; Friedman et al., 1974; Phillips et al., 1974). The lack of aggregation of coronary heart disease in mother-sib pairs also agrees with most earlier reports (Gertler and White, 1954; Thomas and Cohen, 1955; Phillips et al., 1974). The possibility of modest excess mortality of mothers from coronary heart disease or from cerebrovascular diseases found by others (Shanoff et al., 1961; Rose, 1964; Friedman et al., 1974) cannot be totally excluded, however. Part of the higher total mortality of case mothers might have been the result of cardiovascular causes despite divergent diagnoses in the death certificates. It is also possible that latent cardiovascular disease may have increased the susceptibility to death from other causes and coronary heart disease perhaps would have become evident at a later age, if death from other causes had not intervened. A somewhat increased mortality from coronary heart disease could, in fact, be shown for the mothers of the very youngest case probands (Rissanen, 1979). The three- to four fold excess in the rate of coronary heart disease among case sibs observed in this study also agrees with their investigations which have reported two- to tenfold increases in the rate of coronary heart disease among the brothers and two- to fourfold increases among the sisters of affected men (Gertler and White, 1954; Thomas and Cohen, 1955; Russek and Zohman, 1958; Shanoff et al., 1961; Rose, 1964; Slack a.d Evans, 1966; Phillips et al., 1974).

From the above it appears that the excess rate of coronary heart disease in case relatives over that of reference relatives shown here is no greater than in studies from other countries. It should be remembered, however, that the frequencies of coronary heart disease in both case and reference relatives in the present study are remarkably higher than those reported elsewhere. For instance, the risk of coronary heart disease for case brothers in the present study was greater than that for the affected brothers in families with type II familial hypercholesterolaemia in a report from the United States (Stone et al., 1974). As another example, mortality from coronary heart disease of reference fathers of the present study was approximately 5 times greater than that of the fathers of young Hawaiian-Japanese men suffering from coronary heart disease (Phillips et al., 1974).

The relatively modest excess occurrence of coronary heart disease in case relatives over that in reference relatives could be taken to suggest that familial factors play only a minor role in the causation of coronary heart disease. However, even this modest excess may indicate a substantial familial element in the disease of the present study cohort. No multifold excess of familial aggregation should be expected against such a high rate of coronary heart disease as was found in reference relatives. Furthermore, an appreciable proportion of the high rate of coronary heart disease among reference relatives was also attributable to family aggregates of the disease. Almost one-half of the reference sibs affected by coronary heart disease originated from the 5 families in which 1 of the 
parents had died of coronary heart disease before the age of 70 .

Aggregation of coronary heart disease was most distinct in case families in which the mother had died of coronary heart disease at a relatively young age. Approximately one-half of the children of such mothers, whether daughters or sons, had developed coronary heart disease early in life. It appears likely that these mothers possessed and passed to their offspring sets of highly atherogenic genes that were strong enough to outweigh the natural resistance of females to coronary heart disease. Similar clustering of coronary heart disease in families of affected mothers as shown here has been observed previously by Slack and Evans (1966). They suggested also that the genetic component may be more prominent in coronary heart disease in women than in men. This is supported by the present findings.

Since the frequency of coronary heart disease in case families with a paternal history of coronary heart disease before the age of 70 was considerably lower than that in the families with a maternal history, the factors involved in the transmission of susceptibility to coronary heart disease through the paternal line of descent appear less potent and may be qualitatively different from the factors involved in the transmission of disease susceptibility through the maternal line of descent.

Parental history of coronary heart disease was not a prerequisite for a distinct familial aggregation of coronary heart disease. Multiple sibs were affected in several families without any parental history of the disease. It may be argued that the diagnosis of coronary heart disease in a parent was missed in such families. In most of them, however, the parents could be shown to have survived to an old age and to have died of non-cardiac causes. For instance, in the family with the strongest clustering of coronary heart disease, with 7 out of 9 sibs affected at ages 30 to 59 , both parents had enjoyed good health to an old age and succumbed from causes other than coronary heart disease.

The failure to show parent-offspring concordance for coronary heart disease does not exclude the possibility that inherited factors would be important causes of the aggregation of the disease in the offspring. It is possible that the parents were carriers of atherogenic genes which did not become fully expressed until enhanced by an exposure to additional atherogenic factors arising from the changing environment. Such factors are likely to be responsible for the increase observed in the rate of coronary heart disease in the offspring generation.

This increase was modest, however, when compared with the pronounced secular increase in the rate of coronary heart disease which is well documented in the general population. Environmental influences thus do not appear to be major determinants of the development of the disease in case subjects. This impression is substantiated by the fact that in many of the sibships with multiple cases of coronary heart disease, distinctly similar disease histories-both as to the age of onset and the clinical form of the disease-were found in sibs with widely different environments and life styles. For instance, 2 brothers, 1 a resident of Finland and the other of New Zealand for the last 45 years, developed angina at ages 50 and 51 , respectively. Such similarities are likely to arise from shared genetic background.

In some families, especially in a majority of those with a maternal history of coronary heart disease, the number affected by coronary heart disease was high enough to suggest the effect of dominant gene(s), directly causing coronary heart disease. In most families, however, the genetic factors involved are likely to be polygenic. The relatively modest overall aggregation of coronary heart disease among case relatives if compared with reference relatives, as well as the decline in risk of coronary heart disease between case and reference relatives with advancing age, suggest an interplay of multiple factors in the development of this complex disease (Carter, 1969).

The results of the study call attention to the role of family history of coronary heart disease in predicting the future victims of the disease. Screening for parental history of coronary heart disease before the age of 70 would have identified one-third of case probands, most of them with multiple affected sibs, decades before the emergence of the clinical disease. By the same procedure, only 9 per cent of healthy reference men would have been identified. The high rate in the sibs of these men shows that these reference families were in greatest need of preventive action. Admittedly, screening for parental history of coronary heart disease would have been a relatively insensitive test, failing to identify a majority of the future cases of the disease. It is doubtful, however, whether any other single measure would have had a better predictive power in this population with such a high overall risk of coronary heart disease. The sensitivity of screening by family history could have been improved considerably had the history of premature coronary heart disease in a sib also been taken into account. By so doing, two-thirds of the case probands could have been identified before the onset of the clinical disease.

Therefore, at least in Finland, family history of coronary heart disease should be recognised as a 
major risk factor, which is well suited, and should also be used as a simple screening test for coronary prone individuals.

This study was supported by personal grants from the Yrjö Jahnsson and Paavo Ahvenainen Foundations and by a grant to Professor Esko Nikkilä from Finnish State Medical Council. The data analysis of the present study was performed during the author's term as visiting fellow, Epidemiology Branch Division of Cardiovascular Diseases, NHBLI, Bethesda, Maryland. The author wishes to thank Aino Korpela, statistician, head of the mortality register in Finland, for coding the causes of death.

\section{References}

Carter, C. O. (1969). Genetics of common disorders. British Medical Bulletin, 25, 52-57.

Cederlöf, J. R., Friberg, L., and Johnsson, E. (1967). Hereditary factors and 'angina pectoris'. A study on 5,877 twin pairs with the aid of mailed questionnaires. Archives of Environmental Health, 14, 397-400.

Cutler, S. J., and Ederer, F. (1958). Maximum utilization of the life table method in analyzing survival. Fournal of Chronic Diseases, 8, 699-712.

de Faire, U., Friberg, V., and Lundman, T. (1975). Concordance for mortality with special reference to ischemic heart disease and cerebrovascular disease. A study on the Swedish Twin Registry. Preventive Medicine, 4, 509-517,

Deutscher, S., Ostrander, L. O., and Epstein, F. H. (1970). Familial factors in premature coronary heart disease-a preliminary report from the Tecumseh Community Health Study. American fournal of Epidemiology, 91, 233-237.

Edwards, J. H. (1963). The genetic basis of common disease. American fournal of Medicine, 34, 627-638.

Epstein, F. H. (1964). Hereditary aspects of coronary heart disease. American Heart fournal, 67, 445-456.

Epstein, F. H., and Kjelsberg, M. O. (1965). Coronary heart disease in relation to blood pressure and cholesterol levels in population studies. In Genetics and the Epidemiology of Chronic Diseases, pp. 265-277, ed J. V. Neel, M. W. Shaw, and W. J. Schull. USPHS Publication No 1163, Government Printing Office, Washington, DC.

Epstein, F. H., and Krueger, D. R. (1969). The changing incidence of coronary heart disease. In Modern Trends in Cardiology, 2, pp. 17-35, ed A. Morgan Jones. Butterworths, London.

Frank, C. W., Weinblatt, E., and Shapiro, S. (1973). Angina pectoris in men. Prognostic significance of selected medical factors. Circulation, 47, 509-517.

Friedman, C. D., Klatsky, A. L., Siegelaub, A. B., and McCarthy, N. (1974). Kaiser-Permanente epidemiologic study of myocardial infarction. American fournal of Epidemiology, 99, 101-116.

Gertler, M. M., and White, P. D. (1954). Coronary Heart Disease in Young Adults; A Multidisciplinary Study. Harvard University Press, Cambridge, Massachusetts.

Haenszel, W. (1950). Problems in the estimation of familial risks of disease. Fournal of the National Cancer Institute, 23, 487-505.

Hammond, E. C., Garfinkel, L., and Seidman, H. (1971). Longevity of parents and grandparents in relation to coronary heart disease and associated variables. Circulation, 43, 31-44.

Harvald, B., and Hauge, M (1970). Coronary occlusion in twins. Acta Geneticae Medicae et Gemellologiae, 19, 248-250.

Liljefors, I. (1970). Coronary heart disease in male twins: hereditary and environmental factors in concordant and discordant pairs. Acta Medica Scandinavica, Suppl. 511.

Mantel, N. (1966). Evaluation of survival data and two new rank order statistics arising in its consideration. Cancer Chemotherapy Reports, 50, 163-170.

McMichael, A. J., Haynes, S. G., and Tyroler, H. A. (1975). Observations in the evaluation of occupational mortality data. Fournal of Occupational Medicine, 17, 128-131.

Murphy, E. A. (1967). Some difficulties in the investigation of genetic factors in coronary artery disease. Canadian Medical Association fournal, 97, 1181-1192.

Napier, J. A., Metzner, H., and Johnson, B. C. (1972). Limitations of morbidity and mortality data obtained from family histories - a report from the Tecumseh Community Study. American fournal of Public Health, 62, 10-35.

Phillips, R. L., Lilienfeld, A. M., Diamond, E. L., and Kagan, A. (1974). Frequency of coronary heart disease and cerebrovascular accidents in parents and sons of coronary heart disease index cases and controls. American fournal of Epidemiology, 100, 87-100.

Puska, P., and Mustaniemi, H. (1975). Incidence and presentation of myocardial infarction in North Karelia, Finland. Acta Medica Scandinavica, 197, 211-216.

Rissanen, A. (1979). Familial occurrence of coronary heart disease. Effect of age at diagnosis. American fournal of Cardiology. In press.

Rose, G. (1964). Familial patterns in ischaemic heart disease. British fournal of Preventive and J́ncial Medicine, 18, 75-80.

Russek, H. I., and Zohman, B. L. (19j8). Relative significance of heredity, diet and occupational stress in coronary heart disease of young adults. American fournal of the Medical Sciences, 235, 266-277.

Shanoff, H. M., Little, A., Murphy, E. A., and Rykert, H. E. (1961). Studies of male survivors of myocardial infarction due to 'essential' atherosclerosis. I. Characteristics of the patients. Canadian Medical Association fournal, 84, 519-530.

Sholtz, R. I., Rosenman, R. H., and Brand, R. J. (1975). The relationship of reported parental history to the incidence of coronary heart disease in the Western Collaborative Group Study. American fournal of Epidemiology, 102, 350-356.

Slack, J., and Evans, K. A. (1966). The increased risk of death from ischaemic heart disease in first degree relatives of 121 men and 96 women with ischaemic heart disease. Fournal of Medical Genetics, 3, 239-257.

Stone, N. J., Levy, R. I., Fredrickson, D. S., and Verter, J. (1974). Coronary artery disease in 116 kindred with familial type II hyperlipoproteinemia. Circulation, 49, 476-488.

Thomas, C. B., and Cohen, B. H. (1955). The familial occurrence of hypertensivii and coronary artery disease, with observations concerning obesity and diabetes. Annals of Internal Medicine, 42, 90-127.

White, P. D. (1960). The importance of heredity in coronary heart disease. Circulation, 22, 269-300.

World Health Organization. Regional Office for Europe (1971). Report on the Fifth Working Group. WHO/ EURO 9201(5), the Organization, Copenhagen.

Requests for reprints to Dr Aila Rissanen-Tukiainen, Third Department of Medicine, University of Helsinki, 00290 Helsinki 29, Finland. 